\title{
\#PauloFreire100Anos - transformação social e cultura digital: Memórias freirianas nas ações da UNIFESP - UAB
}

\section{\#Paulo Freire 100 Years - social transformation and digital culture: Freirean memories in the actions of UNIFESP-UAB}

\section{\# PauloFreire100Anos - transformación social y cultura digital: Recuerdos freirianos en la actuación de UNIFESP - UAB}

\author{
Lucila Maria Pesce, Claudia Coelho Hardagh, Luciano Gamez, Valéria Sperduti Lima, Sylvia Helena \\ Souza da Silva Batista, Rosângela Aparecida Dantas de Oliveira, Mariângela Graciano
}

\section{RESUMO}

“\#Paulo Freire100Anos: transformação social e cultura digital” foi um evento científico internacional organizado por professores da Unifesp (Universidade Federal de São Paulo) no âmbito do Projeto FORMA de extensão e pesquisa, com apoio da Unifesp-UAB, para homenagear o centenário de Paulo Freire e provocar diálogos e reflexões sobre a epistemologia freiriana no contexto da cultura digital. Pesquisadores da América Latina, Europa e Brasil trouxeram suas pesquisas e práxis pedagógica para refletir de que modo o pensamento emancipador de Paulo Freire nos ajuda a entender as transformações tecnológicas e como a consolidação da cultura digital afetou a educação, principalmente no atual período pandêmico. As reflexões de Paulo Freire acerca das tecnologias na década de 1990, a inserção dos computadores nas escolas públicas no município de São Paulo - quando exerceu o cargo de secretário da educação - são fundamentais para a leitura crítica da cultura digital e seus efeitos na sociedade contemporânea. É imprescindível que Paulo Freire - como patrono da educação brasileira, referência nacional e internacional - contribua para os estudos sobre educação, justiça social e cultura digital em uma perspectiva crítica e emancipadora. Para celebrar os 100 anos de nascimento de Paulo Freire e em respeito à sua memória, docentes de vários campi da Unifesp organizaram, de março a setembro de 2021, uma série de ações, que abarcaram a produção de vídeos de narrativas de educadores, cursos on-line de extensão, diversas palestras proferidas e a organização de um livro que traz conceitos clássicos da filosofia da práxis, sob enfoque freiriano. A celebração culminou com o evento "\#Paulo Freire100Anos: transformação social e cultura digital" ocorrido em setembro de 2021. O evento online proporcionou três dias de intensos diálogos entre pesquisadores e educadores que trazem em sua práxis a essência freiriana da esperança e da liberdade. Entendemos que as obras de Freire foram negligenciadas nos últimos anos pelas universidades, por políticas públicas que se afastaram das bases populares e por interpretações equivocadas que deturparam seus pensamentos e ações que refletem uma vida dedicada ao empoderamento da classe trabalhadora. Acreditamos que a universidade pública tem o compromisso de disseminar e trazer novas contribuições de suas teorias, para que as novas gerações conheçam, discutam e produzam novas práxis emancipadoras. O pensamento freiriano nos ensina e inspira a, por meio da educação e de mais amorosidade acadêmica, formar uma geração de cidadãos que tenham respeito à democracia, à liberdade e

Submetido em: 06/10/2021 - Aceito em: 06/10/2021 - Publicado em: 13/10/2021 


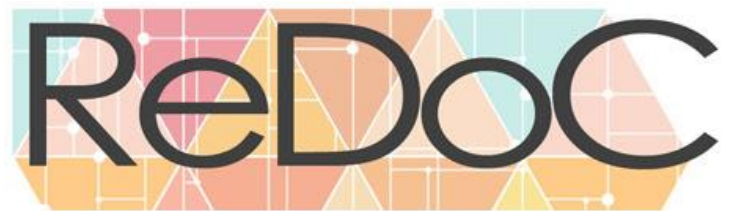

\title{
Revista Docência e Cibercultura
}

lutem pela justiça social e pela equidade em nosso país. Esse foi o intuito das memórias freirianas tecidas na Unifesp - UAB, no decurso de 2021.

PALAVRAS-CHAVE: centenário de Paulo Freire; memórias e diálogos; cultura digital e transformação social; práxis pedagógica.

\begin{abstract}
Paulo Freire100Anos: social transformation and digital culture” was an international scientific event organized by professors from Unifesp (Federal University of São Paulo) under the FORMA Project of extension and research, with support from Unifesp-UAB, to honor the centenary of Paulo Freire and promote dialogues and reflections on Freire's epistemology in the context of digital culture. Researchers from Latin America, Europe and Brazil brought their research and pedagogical praxis to reflect on how Paulo Freire's emancipatory thought helps us to understand technological transformations and how the consolidation of digital culture affected education, especially during the pandemic period. Paulo Freire's reflections on technologies in the 1990s, the insertion of computers in public schools in the city of São Paulo - when he held the position of secretary of education - are fundamental for a critical reading of digital culture and its effects on contemporary society. It is essential that Paulo Freire - as a patron of Brazilian education, a national and international reference - contributes to studies on education, social justice, and digital culture in a critical and emancipatory perspective. To celebrate the 100th anniversary of Paulo Freire's birth and out of respect for his memory, professors from Unifesp organized, from March to September 2021, a series of actions, which included the production of videos of educators' narratives, online courses extension, several lectures and the organization of a book that bring classic concepts of the philosophy of praxis, according to a Freire's approach. The celebration culminated with the event "\#Paulo Freire100Anos: social transformation and digital culture" held in September 2021. The online event provided three days of intense dialogue among several researchers and educators who bring in their praxis the Freire's essence of hope and freedom. We understand that Freire's works have been neglected in recent years by universities, by public policies that have moved away from popular bases and by misinterpretations that distorted his thoughts and actions that reflect a life dedicated to the empowerment of the working class. We believe that the public university is committed to disseminating and bringing new contributions to its theories, so that new generations can get to know, discuss, and produce new emancipatory praxis. Freire's ideas teach and inspires us, through education and more academic love, to form a generation of citizens who respect democracy, freedom and fight for social justice and equity in our country. This was the purpose of the Freire's memories woven at Unifesp-UAB, in the course of 2021.
\end{abstract}

KEYWORDS: centenary of Paulo Freire; memories and dialogues; digital culture and social transformation; pedagogical praxis.

RESUMEN: “\#Paulo Freire100Anos: transformación social y cultura digital” fue un evento científico internacional organizado por profesores de la Unifesp (Universidad Federal de São Paulo) en el marco del Proyecto FORMA de extensión e investigación, con el apoyo de la Unifesp-UAB, para honrar el centenario de Paulo Freire y provocar diálogos y reflexiones sobre la epistemología de Freire en el contexto de la cultura digital. Investigadores de América Latina, Europa y Brasil aportaron su investigación y praxis pedagógica para reflexionar sobre cómo el pensamiento emancipador de Paulo Freire nos ayuda a comprender las transformaciones tecnológicas y cómo la consolidación de la cultura digital afectó a la educación, especialmente durante el actual período pandémico. Las reflexiones de Paulo Freire sobre las tecnologías en la década de 1990, la inserción de las computadoras en las escuelas públicas de la ciudad de São Paulo, cuando ocupaba el cargo de secretario de educación, son fundamentales para una lectura crítica de la cultura digital y sus efectos en la sociedad contemporánea. Es fundamental que Paulo Freire, como mecenas de la educación brasileña, referencia nacional e internacional, contribuya a los estudios sobre educación, justicia social y cultura digital en una perspectiva crítica y emancipadora. Para celebrar el centenario del nacimiento de Paulo Freire y por respeto a su memoria, profesores de varios campi de la Unifesp organizaron, de marzo a septiembre de 2021, una serie de acciones, que incluyeron 
la producción de videos de narrativas de educadores, cursos en línea de extensión, varias conferencias y la organización de un libro que acerca conceptos clásicos de la filosofía de la praxis, bajo un enfoque freireano. La celebración culminó con el evento "\#Paulo Freire100Anos: transformación social y cultura digital” realizado en septiembre de 2021. El evento en línea brindó tres días de intenso diálogo entre investigadores y educadores que traen en su praxis la esencia freiriana de esperanza y libertad. Entendemos que las obras de Freire han sido desatendidas en los últimos años por las universidades, por políticas públicas que se han alejado de las bases populares y por malas interpretaciones que distorsionaron sus pensamientos y acciones que reflejan una vida dedicada al empoderamiento de la clase trabajadora. Creemos que la universidad pública se compromete a difundir y aportar nuevos aportes a sus teorías, para que las nuevas generaciones puedan conocer, debatir y producir nuevas praxis emancipadoras. El pensamiento freiriano nos enseña e inspira, a través de la educación y más amor académico, a formar una generación de ciudadanos que respeten la democracia, la libertad y luchen por la justicia social y la equidad en nuestro país. Este fue el propósito de las memorias freirianas tejidas en Unifesp-UAB, en el transcurso de 2021.

PALABRAS CLAVE: centenario de Paulo Freire; memorias y diálogos; cultura digital y transformación social; praxis pedagógica.

\section{Links gerais para divulgação e acesso:}

Perfil no Facebook: https://www.facebook.com/PAULOFREIRE100ANOS

Canal no Youtube: https://www.youtube.com/channel/UCsUWIxHQJdtFxFh0JwWpQgg

Cards e links de 3 de 15 encontros para divulgação (todos disponíveis nos links gerais):

\section{Profa Ana Saul \\ Pontificia Universidade Católica de São Paulo \\ Conferência de abertura}
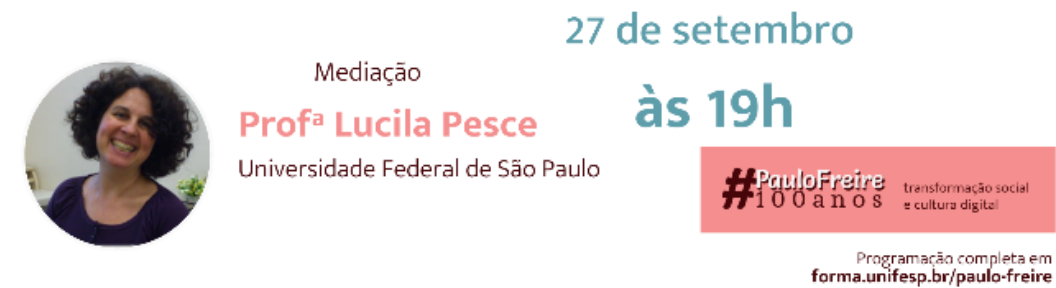

https://www.youtube.com/watch?v=z4kNWQkTQXA\&t=3s 


\section{Prof. Boaventura de Souza Santos}

Universidade de Coimbra

Em breve iniciaremos a conferencia final

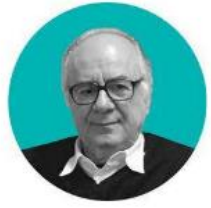

\section{Conferência de} encerramento

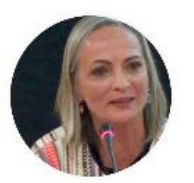

Mediação

Profa Cláudia Hardagh Universidade Federal de São Paulo

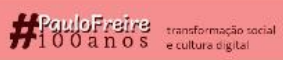

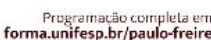

https://www.youtube.com/watch?v=Dgjzit0114Q

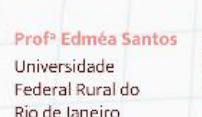

Federal Rural do

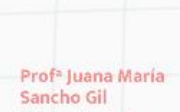

Sancho Gil

Universidade

Barcelona

Prof. Marcelo

Buzato

Universidade Estadual

de Campinas
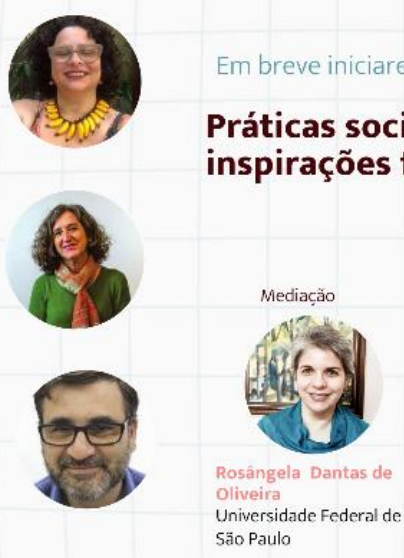

Em breve iniciaremos a mesa..

Práticas sociais no ciberespaço: inspirações freireanas

28 de setembro

$14 \mathrm{~h} 30$ às $16 \mathrm{~h} 30$

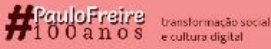

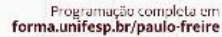

https://www.youtube.com/watch?v=9aqGBRtzrJQ

\section{Agradecimentos}

A todas e todos que mantêm viva a memória, a obra e a causa de Paulo Freire em cada sala de aula dentro e fora do Brasil.

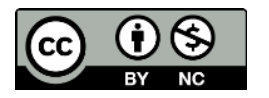

Este é um artigo de acesso aberto distribuído sob os termos da Licença Creative Commons Atribuição Não Comercial-Compartilha Igual (CC BY-NC- 4.0), que permite uso, distribuição e reprodução para fins não comerciais, com a citação dos autores e da fonte original e sob a mesma licença. 